\title{
Pitaya fruit quality (Hylocereus undatus [Haworth] Britton \& Rose) according to physiological maturity. A review
}

\section{Calidad de los frutos de pitaya (Hylocereus undatus [Haworth] Britton \& Rose) en función de la madurez fisiológica. Una revisión}
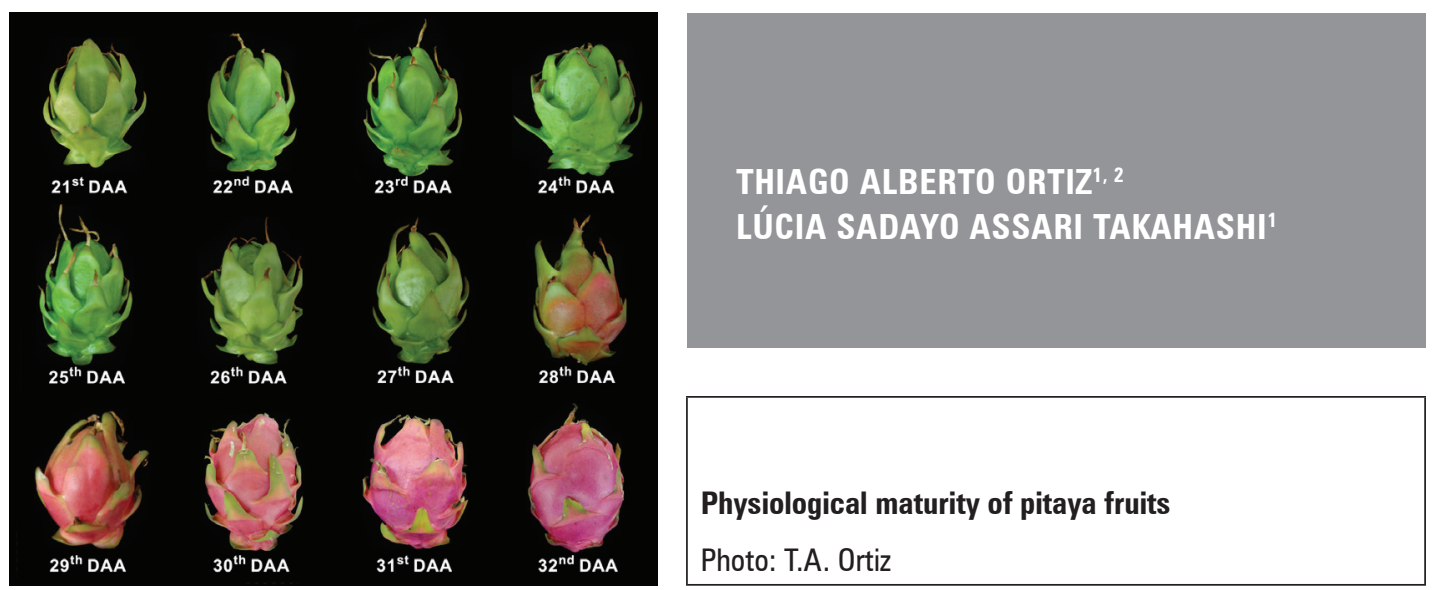

\section{ABSTRACT}

The pitaya fruit has occupied a growing niche in the fruit market because its organoleptic characteristics and rusticity have attracted the attention of consumers and producers, respectively. The organoleptic and nutritional quality of fruits are due to the maturity stage. Therefore, determining the period in which the fruits reach physiological maturity is important since it aids the planning of the harvest and fruit quality control. In this sense, the aim of this review was to establish the ideal period for harvesting pitaya fruits (Hylocereus undatus) by determining the physiological maturity point. For this species, the number of days from anthesis to full development of the fruit has been the most reliable variable to determine harvest timing. With this designation, it is possible to indicate the stage (physiological maturity) in which the fruits present characteristics that are favorable to the species, for example, color, soluble solids content, ratio, and others. The place of production and edaphoclimatic conditions can interfere and cause variation in the period in which fruits reach physiological maturity. Some studies in Mexico have confirmed that the physiological maturation of pitaya fruits occurs between 25 and 31 days after anthesis (DAA). Other research, including in Brazil, has confirmed that this point occurred from 28 to 32 DAA. Thus, based on the scientific studies in the literature, it is recommended to harvest pitaya fruits between 25 and 32 DAA to avoid losing the commercial value of fruits.

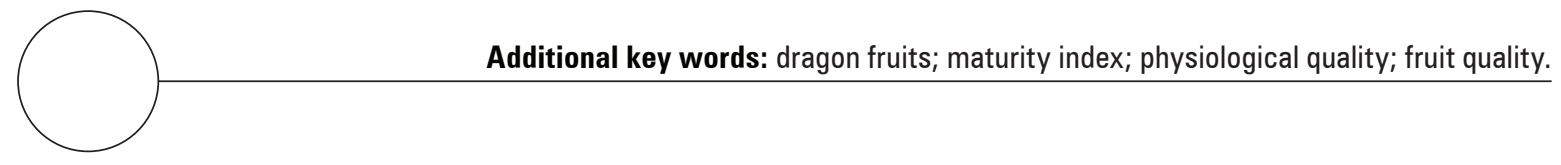

\footnotetext{
1 State University of Londrina, Department of Agronomy, Londrina (Brazil). ORCID Ortiz, T.A.: 0000-0001-8441-1410; ORCID Takahashi, L.S.A.: 0000-0001-6513-7591

2 Corresponding author. thiago.ortiz@hotmail.com
} 


\section{RESUMEN}

Los frutos de pitaya han ocupado un creciente nicho en el mercado de frutas ya que sus características organolépticas y rusticidad han atraído la atención de los consumidores y productores, respectivamente. La calidad organoléptica y nutricional de los frutos son consecuencia de la fase de maduración. Por lo tanto, determinar el período en que los frutos alcanzan la madurez fisiológica es importante, pues apoya la planificación de la cosecha y el control de calidad de los frutos. En este sentido, esta revisión tiene como objetivo establecer el período ideal para realizar la cosecha de los frutos de la pitaya (Hylocereus undatus), a través de la determinación del punto de madurez fisiológica. Para esta especie, el número de días de la antesis hasta el desarrollo pleno del fruto se ha mostrado como la variable con mayor confiabilidad para determinar el momento de la cosecha. A partir de esta designación, es posible indicar la fase (madurez fisiológica) en que los frutos presentan características favorables a la especie, a ejemplo del color, contenido de sólidos solubles, ratio, entre otras. Se sabe que el lugar de producción y las condiciones edafoclimáticas son capaces de interferir y causar variación en cuanto al período en que los frutos alcanzan la madurez fisiológica. Algunos estudios en México confirmaron que la maduración fisiológica de los frutos de pitaya ocurrió entre los 25 y 31 días después de la antesis (DAA). Otras investigaciones, incluso en Brasil, confirmaron que este punto ocurrió en el período de 28 a 32 DAA. Por lo tanto, a partir de los estudios científicos llevados a cabo y publicados en la literatura, para evitar perder su valor comercial de los frutos de pitaya se recomienda cosecharlos entre 25 y 32 DAA.

Palabras clave adicionales: fruta de dragón; índice de madurez; calidad fisiológica; calidad de la fruta.

Received for publication: 18-09-2018 Accepted for publication: 30-03-2020

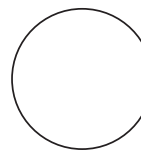

INTRODUCTION

The fruit cultivation is constantly evolving in terms of new varieties and species for commercialization, which have been boosted by consumer awareness of healthy diets. In this sense, pitaya or dragon fruits (Hylocereus undatus [Haworth] Britton \& Rose), a fruit plant belonging to the Cactaceae family, has occupied a growing niche in the fruit market, with wide demand in the global market (Rodríguez, 2000; Le Bellec et al., 2006; Cordeiro et al., 2015).

Thus, with the increase in acceptance of exotic fruits worldwide, pitaya's market has been favored, increasing the economic and agronomic potential of its cultivation (Rodríguez, 2000). The organoleptic characteristics, together with the nutraceutical properties, make pitaya products desirable in consumer markets (Silva et al., 2006; Andrade et al., 2007; Perween et al., 2018). In addition, the plant's rusticity and the aggregate commercial value of the fruits have contributed to expansion of the cultivation of this species, which makes it attractive to fruit growers (Ortíz-Hernández et al., 1999; Bastos et al., 2006; Santos et al. 2010; Xu et al., 2019).

Fruit production depends on intrinsic factors, extrinsic factors and a combination of both, and the organoleptic and nutritional quality depend on the maturation stage (Centurión Yah et al., 2000). The maturation stage of fruits at harvest influences final quality, interfering in the post-harvest process. When fruits are harvested immaturely, the maturing process is impaired, which is reflected in the quality since they become susceptible to physiological disorders, for example, cell disorganization and cell wall disruption. However, fruits harvested at the supermature stage will favor senescence, reducing shelf-life and hampering handling, storage and transport as the result of low physical resistance and sensitivity to injuries and diseases, causing quantitative and qualitative losses (Kays, 1991; Chitarra and Chitarra, 2005).

Fruit maturation is not a clearly event in plant phenology models (Chuine et al., 2003). Thus, in order to obtain a product with commercial value, it is necessary to precisely determine when the fruit reaches physiological maturity, which can be identified by physical parameters (longitudinal length, equatorial diameter, thickness, weight, and color) and/or chemicals parameters (soluble solids content and titratable acidity ratio and $\mathrm{pH}$ ).

Because studies on pitaya are still restricted, little is known about harvest rates and post-harvest behavior of the fruits of this species. In addition, a lack of 
knowledge on pre- and post-harvest techniques for the management of pitaya fruit quality has made it difficult to market them globally (Centurión Yah et al., 2008). Thus, this review aims to establish the ideal period for harvesting pitaya fruits (Hylocereus undatus) by determining the physiological maturity point.

\section{ORIGIN AND MORPHOLOGY OF PITAYA}

Pitaya, part of the Cactaceae family, originated from the tropical and subtropical Americas, whose adaptability to different environmental conditions has favored introduction in countries with edafoclimatic differences (Mizrahi et al., 2002; Tel-Zur et al., 2004). It is grouped into four genera: Stenocereus Briton \& Rose and Cereus Mill. (which they are columnar cactaceae), and Selenicereus (A. Berger) Riccob and Hylocereus Britton \& Rose (both are epiphyte cacti) (Zee et al., 2004; Le Bellec et al., 2006).

The Antilles words 'Pitahaya' or 'Pitaya', meaning fruit covered by scales, are used for both the plant and the fruit (Rodríguez, 1993; Zee et al., 2004). The names for these species include 'Moonflower' and 'Queen of the night' because the flowers open only at night and close in the early hours of the following day, along with the beauty of its flowers, one of the more beautiful in the world (Mizrahi and Nerd, 1999).

In eastern countries, they are known as 'Dragon fruit' because the external bracts resemble dragon scales (Mizrahi and Nerd, 1999; Meráz et al., 2003). However, use of the term 'Pitahaya' has become widespread, not only in Colombia and Nicaragua, where the word 'Pitaya' has been used repeatedly, but also in European and Asian countries where it is traded and where the name 'Pitahaya' is often added to the local designation to better identify it in the market (Rodríguez, 2000; Xu et al., 2019).

Pitaya is an epiphytic, rupiculate or terrestrial branched, perennial and succulent plant. The taxonomic group 'Hylocereus' is diploid, as in most cacti, characterized by plants with a scandal or climbing habit that grow in both trees and rocks (OrtízHernández, 2000). Commercial cultivation commonly uses the staking system in production.

The stem is classified morphologically as cladodium, segmented with trigone or trialled branches, reaching up to $35 \mathrm{~m}$ in length and 5 to $7 \mathrm{~cm}$ in diameter, with wings that have an approximately $2.3 \mathrm{~cm}$ height
(Rodríguez, 1993). The cladodium is succulent, with sharp, creased and horny edges; it is greenish with a photosynthesizing function or greyish with aging because of the wax that covers it (Donadio, 2009). It is devoid of true leaves; however, there are modified leaves, i.e. thorns (Paula and Ribeiro, 2004; Socha, 2007). The stem has a sub-winged areolas with a dilated base in a bulb; they are of 2 to $3 \mathrm{~cm}$ in diameter, 3 to $5 \mathrm{~cm}$ from each other, and have 3 to 6 thorns each that are 1 to $4 \mathrm{~mm}$ long (Donadio, 2009).

Numerous adventitious roots originate from the cladodes in the intercostal spaces that contribute to the absorption of nutrients and anchoring the plant (Rodríguez, 1993; Ortíz-Hernández, 2000). The root system is fasciculate and superficial; however, it has the capacity of extracting nutrients from the soil even when they are at low concentrations (Le Bellec et al., 2006).

The flower is complete, androgynous, solitary, aromatic and lateral, with white or pink coloring, measuring from 20 to $35 \mathrm{~cm}$ in diameter. It contains numerous stamens, with over 800 in a single flower. They are arranged in two rows around the pistil, formed by 14 to 28 cream colored stilettos. The sepals are light green in color. and the pollen is abundant and yellow in color (Crane and Balerdi, 2005; Le Bellec et al., 2006; Donadio, 2009).

In $H$. undatus, flower buds are formed shortly before anthesis, exhibiting rapid development, about three weeks (Nerd et al., 2002b). The anthesis is nocturnal, lasting approximately $15 \mathrm{~h}$. The maximum flower opening occurs between 23.00 and $01.00 \mathrm{~h}$. The emission of floral buds occurs in the areolas, appearing as a bud in each one only once, and other reproductive or vegetative organs are not developed in this region (Marques, 2010). The areolas are protruding or depressed points, where the axillary buds are located. In order to avoid self-pollination, $H$. undatus flowers have higher stigma than anthers (Marques, 2008).

The fruit is a berry, globose or subglobous, and measures from 10 to $20 \mathrm{~cm}$ in diameter, with mass varying from 200 to $1.000 \mathrm{~g}$, but the average mass of the fruit varies from 350 to $450 \mathrm{~g}$ (Nerd and Mizrahi, 1997). Its formation takes place from the development of the ovary (Mizrahi and Nerd, 1999).

According to the species, the fruits may present diversified characteristics, such as shape, presence of thorns and pericarp and pulp color, reflecting high genetic variability (Junqueira et al., 2010). The pericarp 
may have a pink, red or yellow tonality, with foliar scales (bracts) varying in number and length, which are formed from the receptacle surrounding the ovary (Mizrahi and Nerd, 1999). The pulp is juicy, white, red or magenta color; according to the species, with approximately $18^{\circ}$ Brix (Le Bellec et al., 2006; Lorenzi et al., 2006; Livera-Muñoz et al., 2010).

The fruits have climacteric or non-climacteric respiration. In this respect, some studies on pitaya have concluded that it is part of the group of climacterics (Chávez and Stevenson, 1992; Garnica and Quintero, 1994; Camargo and Moya, 1995; Rudas, 1995). However, other authors, based on the low ethylene concentration obtained in their experiments, classified it as non-climacteric (Nerd and Mizrahi, 1997, 1999; Zee et al., 2004; Arévalo-Galarza and Ortíz-Hernández, 2004).

The seeds are distributed numerically throughout the pulp, approximately $3 \mathrm{~mm}$ in diameter, dark in color, obovate in shape, smooth, shiny and with a high germination capacity (Crane and Balerdi, 2005; Le Bellec et al., 2006). Weiss et al. (1994) and Nerd and Mizrahi (1997) observed a positive correlation between fruit mass and number of seeds.

\section{PRODUCTION AND ECONOMIC IMPORTANCE OF PITAYA}

The most widespread pitaya species are the red pericarp (Hylocereus spp.), whose fruits may have white pulp (Hylocereus undatus [Haworth] Britton \& Rose) or red pulp (H. polyrhizus [Weber] Britton \& Rose), and the yellow pericarp (Selenicereus megalanthus [Schum] Britton \& Rose) (Ortíz-Hernández, 2000; Nerd et al., 2002b; Le Bellec et al., 2006).

Among them, the species Hylocereus undatus, red pitaya with white pulp, is the world's most widely cultivated (Nerd et al. 2002a) in Oceania (Australia and New Zealand), Asia (Malaysia, Indonesia, Philippines, Vietnam, Cambodia, Thailand, China, Korea, Taiwan, Japan and Israel), of Europe (Spain), North America (United States and Mexico), Central America (Guatemala, El Salvador, Nicaragua, Costa Rica and Panama), and South America (Colombia, Venezuela, Ecuador, Peru, Uruguay and Brazil) (Rodríguez, 1993; Mizrahi and Nerd, 1999; Xu et al., 2019).

A few decades ago, pitaya was little known but in the 90s received more attention, occupying a growing niche in the exotic fruit market. The number of producing countries of this species has grown, being widely consumed in Asia (Le Bellec et al., 2006, Fernandes et al., 2018; Xu et al., 2019). Significant production is occurring and expanding in many countries, including Colombia, Mexico, Nicaragua, Ecuador, the United States, Thailand, Malaysia, Indonesia, Vietnam, China and Australia (Junqueira et al., 2010; Cavalcante et al. 2011; Paull and Chen, 2019). Vietnam, the leading exporter of pitaya fruits in the world, has almost 40,000 ha devoted to cultivation of this species, with a production volume reaching about 1 million metric tons (ADAWR, 2017).

The interest in this fruit is increasing in consumers because of its organoleptic characteristics and nutraceutical properties (Silva et al., 2006; Andrade et al., 2007). It is a nutritious fruit and can be consumed both in natura or as raw material in a range of industrialized products, such as beverages, cosmetics and medical products (Esquivel, 2004). Some species are rich in flavonoids, vitamins and fibers, besides being a source of vitamin $A$ and $B\left(B_{1}, B_{2}\right.$ and $\left.B_{3}\right)$, phosphorus, calcium, potassium and sodium, with a caloric value of $38 \mathrm{kcal} / 100 \mathrm{~g}$ pulp (Crane and Balerdi, 2005; Wu et al., 2006; Esquivel et al., 2007a; Gunasena et al., 2007; Perween et al., 2018).

On the other hand, fruit growers are attracted by the aggregate commercial value of the pitaya, an alternative for cultivation. In addition, because of its rusticity, it has become an option with agronomic, economic and nutritional potential in shallow, sandy and stony soils (Ortíz-Hernández et al., 1999; Bastos et al., 2006; Santos et al. 2010; Xu et al., 2019).

Pitaya propagation can be with seeds or vegetative structures, notably cutting, grafting and micropropagation. The average productivity of this species is variable according to the soil and climatic conditions, cultivation techniques and orchard age, ranging from 10 to $30 \mathrm{t} \mathrm{ha}^{-1}$ (Le Bellec et al., 2006). Vaillant et al. (2005) confirmed that, in Nicaragua, well-managed crops can produce up to $26 \mathrm{t} \mathrm{ha}^{-1}$. Bastos et al. (2006) reported, in Brazil, an average yield of $14 \mathrm{t} \mathrm{ha}^{-1}$, and, according to Nguyen et al. (2015), yield averages 22$35 \mathrm{t} \mathrm{ha}^{-1}$ in Vietnam.

\section{PHYSIOLOGICAL MATURITY OF PITAYA FRUITS}

The fruits go through a series of transformations during the development process. Fruit ripening is a complex and genetically programmed process, resulting 
in changes in color, aroma, texture and taste, which are important to consumer acceptance. However, it is necessary to determine the point of harvest because its absence causes post-harvest losses in fruits and vegetables. Reducing post-harvest losses and quality deterioration are essential to increasing food availability from existing production. Minimizing this loss is important to food security, economic growth and social welfare (Ayub et al., 1996; Kasso and Bekele, 2018).

In the pitaya crop, the annual flowering period is related to the cultivation region because it is dependent on the photoperiod, characterized here as long days (Nerd et al., 2002b; Luders and McMahon, 2006). However, it is important to determine the period in which the fruits reach physiological maturity to optimize harvest and obtain quality product since edaphoclimatic conditions may exert influence during the development of the fruits.

The importance of determining the appropriate phase for fruit harvest means it is necessary to evaluate the pattern of growth and development after flowering, helping to establish maturation indices based on both environmental and varietal variations that are practical for efficient use by producers (Cavalini, 2004).

A properly timed harvest requires a determination of the physiological maturity stage of the fruit, which be identified by physical parameters, such as longitudinal length, equatorial diameter, mass, shape, color and firmness, and/or with chemicals using the soluble solids content, titratable acidity, and $\mathrm{pH}$, among others. However, one of the criteria used in determining the harvest point is number of days of anthesis until full development of the fruit (Warrington et al., 1999; Lemos et al., 2018).

The determination of the physiological maturity phase based solely on fruit appearance is empirical since it is a subjective measure subject to variations and errors. In this sense, the maturation stages of some species are defined by the pericarp color, which is used by consumers to judge maturity (Kays, 1991; Cavalini, 2004).

According to Thé et al. (2001), pericarp color is closely related to fruit maturation and climatic conditions during the growth period. Color is an important parameter for producers and consumers because it indicates whether the fruit has the ideal conditions for commercialization and consumption. However, color in most cases does not contribute to an effective increase in the nutritional value or quality of the product (Chitarra and Chitarra, 2005), but consumers prefer fruits with a bright and strong color.

The literature reports that the first change in the pericarp color in $H$. undatus occurs between 24 and 29 days after anthesis (DAA), becoming completely red between 2 and $5 \mathrm{~d}$ after the first color change (Castillo-Martínez and Ortíz-Hernández, 1994; Nerd et al., 1999; Centurión Yah et al., 2008; Ortiz and Takahashi, 2015). Centurión Yah et al. (2008) and Ortiz and Takahashi (2015) obtained completely red fruits at 31 and 30 DAA, respectively.

Previously unpublished images obtained from studies by Ortiz and Takahashi (2015) are in this literature review to make this study more instructive and illustrative (Fig. 1).

For the maturation of pitaya fruits, studies have observed a reduction in the hue color angle $\left(h^{\circ}\right)$, that is, fruits changed from green to red when they reached physiological maturity (Centurión Yah et al., 2008; Ortiz and Takahashi, 2015). Van To et al. (2002) confirmed that the range of $h^{\circ}$ in pitaya fruits suitable for marketing must be equal to or less than $30^{\circ}$. Osuna Enciso et al. (2011) obtained completely mature fruits with values below $30^{\circ}$.

According to Wybraniec and Mizrahi (2002) and Le Bellec et al. (2006), the red coloration of Hylocereus spp. fruit pericarp is due to betacyanin pigments, whose synthesis is activated by a high availability of sugars and light, among other factors (Castellar et al., 2003). Phebe et al. (2009) found a significant negative correlation between hue color angle values and total content of betacyanins in $H$. polyrhizus pericarp, with a drastic increase of $90 \%$ in betacyanins between 25 and 30 DAA.

Another important characteristic to take into consideration in pitaya fruits is luminosity since contrasts in luminosity make fruits more attractive. Thus, the lightness index $\left(L^{*}\right)$ has been evaluated in studies carried out to determine the time at which pitaya fruits reach physiological maturity (Ortiz and Takahashi, 2015).

Centurión Yah et al. (2008) did not obtain significant differences when analyzing the lightness index during the development of $H$. undatus fruits. However, Ortiz and Takahashi (2015) observed that $L^{*}$ 
decreased in fruits of this same species, which is not to say that the fruits became less attractive; however, they verified that chroma $\left(C^{*}\right)$ increased with maturation, indicating that the pericarp color became more intense, which would possibly increase its acceptance by consumers.

According to Tucker (1993), Chitarra and Chitarra (2005) and Silva et al. (2019), the reduction of green in fruit pericarp is a process of color change that, in addition to allowing the appearance of the typical color of the analyzed species, is indicative of the maturation stage in fruits and the harvest point. Therefore, the evolution of coloring in pitaya fruits from $21^{\circ}$ to $32^{\circ} \mathrm{DAA}$ through the external and internal fruit pericarp (Fig. 1 and 2) shows the reduction of green in the pericarp and the beginning of the typical coloration of this species starting at the $28^{\text {th }}$ DAA, becoming completely red at 30 DAA.

In addition to color, fruit size variability is also used to define fruit maturation stages (Ortiz and Takahashi, 2015; Almanza-Merchan et al., 2016; Chacón-Padilla and Monge-Pérez, 2016). Ortiz and Takahashi (2015) did not find a significant difference in the longitudinal length during the evolution of the maturation of pitaya fruits from $21^{\text {st }}$ to $32^{\text {nd }} \mathrm{DAA}$, which ranged from 10.6 to $11.7 \mathrm{~cm}$. However, Centurión Yah et al. (2008) obtained an increase in this parameter with proximity to physiological maturity, obtaining fruits

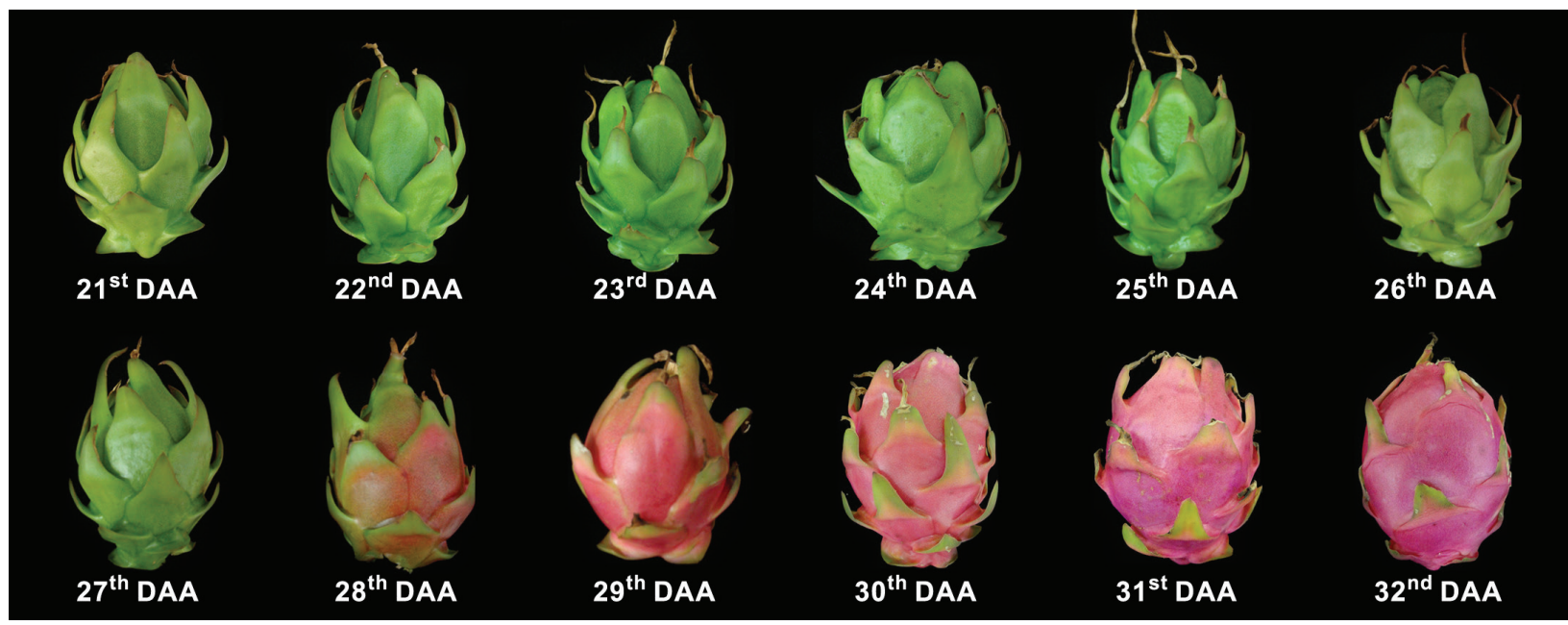

Figure 1. Transition in the external coloring of the pericarp of pitaya fruits. DAA, days after anthesis.

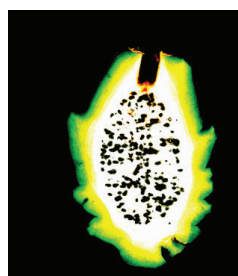

$21^{\text {st }}$ DAA

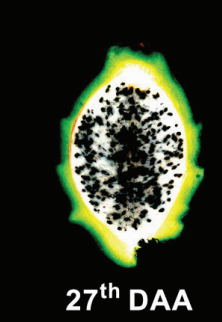

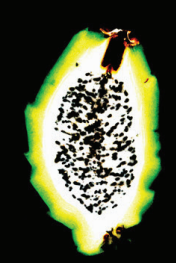

$2^{\text {nd }}$ DAA

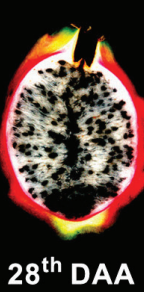

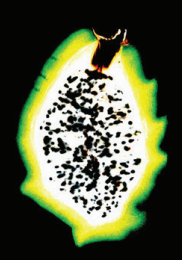

$23^{\text {rd }}$ DAA

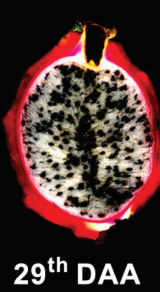

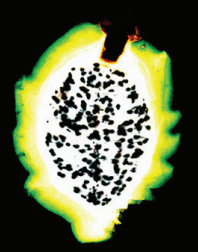

$24^{\text {th }}$ DAA

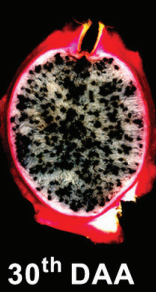

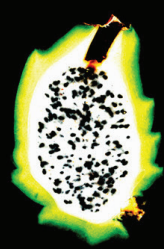

$25^{\text {th }}$ DAA

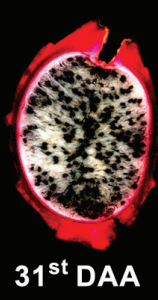

Figure 2. Transition in the internal coloring of the pericarp of pitaya fruits. DAA, days after anthesis. 
with a longitudinal length of $8.9 \mathrm{~cm}$ at $31 \mathrm{DAA}$; Osuna Enciso et al. (2007) reported fruits of this species with a mean longitudinal length of $14.3 \mathrm{~cm}$.

The equatorial diameter of pitaya fruits has also been reported in the literature with a continuous increase as the physiological maturity advances, obtaining mature fruits between 7.9 and $8.2 \mathrm{~cm}$ (Osuna Enciso et al., 2007; Ortiz and Takahashi, 2015; Centurión Yah et al., 2008). Martínez (2011) observed Hylocereus spp. fruits with an equatorial diameter varying from 5.2 to $7.8 \mathrm{~cm}$.

Other characteristics were studied and reported in the literature during the evolution of the maturation of pitaya fruits, including pericarp and pulp thickness. According to Ortiz and Takahashi (2015), the pericarp and pulp thickness presented a decreasing and increasing tendency, respectively, from the $21^{\text {st }}$ to the $32^{\text {nd }}$ DAA. They observed that the pericarp thickness reduced from 1.06 to $0.17 \mathrm{~cm}$ and the pulp thickness increased from 4.60 to $7.17 \mathrm{~cm}$ (Fig. 2). Martínez (2011), when evaluating six pitaya genotypes, obtained materials with a pericarp thickness from 0.22 to $0.42 \mathrm{~cm}$, and Castillo-Martínez et al. (2005) reported a thicknesses from 0.26 to $0.37 \mathrm{~cm}$ when studying five $H$. undatus genotypes.

Fruit, pulp and pericarp mass have been considered when determining the physiological maturity point of pitaya fruits. Ortiz and Takahashi (2015) observed that the fruit and pulp mass showed an increasing tendency from $21^{\circ}$ to $32^{\circ} \mathrm{DAA}$, varying from 293.1 to $416.2 \mathrm{~g}$ and from 87.6 to $253.3 \mathrm{~g}$, respectively. Centurión Yah et al. (2008) observed the same trend, reporting a fruit and pulp mass of 469.2 and $368.9 \mathrm{~g}$ at 31 DAA, respectively.

Osuna Enciso et al. (2007) reported an average fruit mass of $442.0 \mathrm{~g}$, and Nerd et al. (1999) recorded 437.5 g. Castillo-Martínez et al. (2003); Osuna Enciso et al. (2007) and Castillo-Martínez et al. (2005) observed pitaya fruits with a pulp mass of 188.4 to $297.8 \mathrm{~g}$ and from 139.6 to $320.1 \mathrm{~g}$, when working with five H. undatus genotypes, respectively. For pericarp mass, Centurión Yah et al. (2008); Ortiz and Takahashi (2015) reported decreasing trends following anthesis. The authors concluded that, with as maturation of pitaya fruits advanced, the pericarp mass tends to decrease, and the pulp mass tends to increase, which is desired by consumers. Castillo-Martínez et al. (2005) and Martínez (2011), working with different $H$. undatus genotypes, obtained fruits with a pericarp mass from
72.4 to $120.5 \mathrm{~g}$ and from 57.9 to $140.6 \mathrm{~g}$, respectively, reflecting variability within the species.

The progression of pericarp and pulp percentage of pitaya fruits during maturation has also been studied, and Ortiz and Takahashi (2015) noted that from the $21^{\text {st }}$ to the $32^{\text {nd }}$ DAA the pericarp percentage of the fruits decreased from 71.3 to $34.0 \%$, and there was an increase in the pulp percentage from 28.7 to $66.0 \%$, which is favorable and expected since the pulp is the edible portion of the fruit.

Castillo-Martínez et al. (2005) reported H. undatus fruits with $73.0 \%$ pulp, and Osuna Enciso et al. (2007), at 31 DAA, reported 79.0\%. Martínez (2011), working with six pitaya genotypes, evaluated materials that had 40.5 to $80.6 \%$, and it is possible to observe that there is intraspecific variation in this variable. As for the pericarp, Centurión Yah et al. (2008) obtained ripe pitaya fruits with $20.4 \%$ pericarp, and Nerd et al. (1999) reported 32.5\%.

Thus, Ortiz and Takahashi (2015) observed that the pulp/pericarp ratio showed a tendency to increase throughout harvest from 0.40 at 21 DAA to 1.98 at 32 DAA because of the increase in pulp mass and the decline of pericarp mass. Centurión Yah et al. (2008) observed an increased pulp/pericarp ratio, from 1.5 to 3.9 from $25^{\text {th }}$ to $31^{\text {st }} D A A$.

In addition to the physical transformations during fruit maturation, several biochemical transformations also occur, including the increase in soluble solids and the reduction of titratable acidity. According to Gross et al. (2016), there is a relationship between these variables and the maturation stage of the fruit.

The soluble solids content is dependent on the maturation stage and generally increases during maturation evolution through biosynthesis or degradation of polysaccharides (Chitarra and Chitarra, 2005). Some authors evaluated the soluble solids content in pitaya fruits and observed an increase in this variable with the advancement of maturation, obtaining ripe fruits with 12.2 Brix (Ortiz and Takahashi, 2015) and 13.6 'Brix (Osuna Enciso et al., 2011). Other authors, when evaluating different pitaya genetic materials, reported values from 10.9 to $14.1^{\circ} \mathrm{Brix}$ (CastilloMartínez et al., 2005), 14.5 to $17.6^{\circ}$ Brix (Martínez, 2011), 12.0 to $16.0^{\circ}$ Brix (Livera-Muñoz et al., 2010) and 16.0 to $17.0^{\circ}$ Brix (Nerd et al., 1999). Centurión Yah et al. (2008), working with $H$. undatus, observed a close relationship between color development and 
soluble solids increases, where fruits with $20 \mathrm{~d}$ of development recorded $4.6^{\circ}$ Brix, while at $31 \mathrm{~d}$ they reached $12.6^{\circ}$ Brix.

An important aspect that has an effect on the concentration of soluble solids in the pulp is the exposure of the fruit to light during growth because it activates the formation of pigments responsible for the red coloring of the pericarp, betacyanin compounds and sugars in the pulp (Castellar et al., 2003; Esquivel et al., 2007b).

For Centurión Yah et al. (2008), the taste of the pitaya fruit ranged from bittersweet to sweet between 27 and $31 \mathrm{DAA}$, and the highest fruit acceptance was between 29 and 31 DAA. According to Nerd et al. (1999), the accumulation of sugars during the maturation of pitaya fruits is related to a decrease in the content of starch and mucilages in the pulp; there is no contribution to metabolism from the pericarp, as occurs in Opuntia ficus-indica (L.) Miller fruits (De La Barrera and Nobel, 2004).

Titratable acidity is another chemical variable used in the evaluation of the physiological maturity of pitaya fruits; Osuna Enciso et al. (2011) and Ortiz and Takahashi (2015) reported ripe fruits with an acidity of 0.63 and $0.27 \%$, respectively. According to Centurión Yah et al. (1999), fruits with a titratable acidity of $0.24 \%$ present an acceptable flavor for consumers.

Several other authors, evaluating the fruit acidity of Hylocereus spp., reported different values, such as 0.24\% (Centurión Yah et al., 1999), 0.30\% (Sornyatha and Anprung, 2009), 0.36\% Arévalo-Galarza and Ortíz-Hernández, 2004), 0.40\% (Centurión Yah et al., 2008) and between 0.30 and $0.60 \%$, when studying six genotypes (Martínez, 2011).

In fruits of $H$. undatus and $H$. polyrhizus, Nerd et al. (1999) found that the acidity was higher in colorchanging fruits than in fruits with advanced coloring, as did Ortiz and Takahashi (2015) in H. undatus. According to Arévalo-Galarza and Ortíz-Hernández (2004), the increase of acidity before a color change shows the beginning of the maturation process. In addition, a reduction of acidity is a problem in pitaya pulp since this indicator does not detect the sweetness of the fruit.

Thé et al. (2001) and Cavalini (2004) indicated that the ratio provides an indication of fruit flavor since it relates the amount of sugars and acids present. This relationship tends to increase during maturation because of the increase of sugars and the decrease of acids, evidencing the conditions of harvest, storage and immediate consumption.

However, Chitarra and Chitarra (2005) recommend caution in establishing this relationship because insipid fruits, containing low levels of soluble solids and acids, present high ratios, which can lead to erroneous interpretations of quality. As reported by Osuna Enciso et al. (2011), the increase in the ratio of pitaya fruits is due to the drastic reduction in titratable acidity, not an indicator of quality since soluble solids do not increase. Martínez (2011) and Centurión Yah et al. (2008) also observed that the increase in the ratio was due to the decrease in acidity. However, Ortiz and Takahashi (2015) found that in addition to the titratable acidity reduction, the increase in soluble solids content also contributed to the increase in the ratio in $H$. undatus fruits.

For Van To et al. (2002), the best indicator of flavor in pitaya is the ratio, whose ideal value is around 40 . Ratios higher than recommended were reported by Ortiz and Takahashi (2015), who obtained ripe fruits with a ratio of 55.5 at 32 DAA. However, Centurión Yah et al. (2008) obtained fruits with a ratio of 35.5 at 31 DAA. Martínez (2011), when evaluating six pitaya genotypes, obtained materials with a ratio ranging from 33.1 to 48.6.

For $\mathrm{pH}$, Esquivel et al. (2007b) reported pitaya fruits (Hylocereus spp.) with a pH between 4.2 and 4.9, and Stintzing and Carle (2006) reported a value between 4.3 and 4.7. Similar values were cited by Ortiz and Takahashi (2015) in fruits considered mature (32 DAA), with an average $\mathrm{pH}$ of 4.6. However, Cálix de Dios and Castillo-Martínez (2008) reported a pH of 1.7 in the H. undatus subspecies luteocarpus.

Some aspects are important to timing the harvest of pitaya fruits, such as the pericarp color, which is considered determinant, in addition to soluble solids content and ratio. However, the number of days of anthesis to full fruit development has been considered one of the criteria that are commonly used in determining the harvest point (Nerd et al., 1999; Warrington et al., 1999).

Centurión Yah et al. (2008) observed that the physiological maturity of pitaya fruits (H. undatus) in Yucatán-Mexico occurred between $25^{\text {th }}$ and $31^{\text {st }}$ DAA because, in this period, the color of the pericarp varied 
from light green mixed with incipient red tones to purple-red on the entire surface. These authors also observed that, at $31 \mathrm{DAA}$, growth was still active although this age was considered the harvest limit in order to avoid cracking of the pericarp. During the evolution of the maturation, there was accumulation of the edible portion of the fruit and increases in the content of reducing sugars, soluble solids and ratio; however, firmness and acidity were reduced. The authors concluded that there was variation in flavor, from bittersweet to sweet in fruits harvested between the $29^{\text {th }}$ and $31^{\text {st }}$ DAA, the most accepted by consumers.

Castillo-Martínez and Ortíz-Hernández (1994) observed that the development period of $H$. undatus fruits in Oaxaca-Mexico occurs from May to September, with physiological maturity from $31^{\text {st }}$ to $41^{\text {st }}$ DAA. The onset of maturation in pitaya fruits is characterized by a color change in the pericarp between the $24^{\text {th }}$ and $25^{\text {th }} \mathrm{DAA}$; maturation entails the first manifestation of red coloration in the pericarp until the appearance of a brindle brown color. However, because of the subsequent loss of the commercial value of the fruit, these authors stated that the useful harvest stage occurs from the $25^{\text {th }}$ to the $31^{\text {st }}$ DAA. Similar periods for the stage in which fruits of this species reach physiological maturity were obtained by other authors, such as from $28^{\text {th }}$ to $30^{\text {th }}$ DAA (Van To et al., 2002) and from $25^{\text {th }}$ to $31^{\text {st }}$ DAA (Martínez, 2011).

Nerd et al. (1999) reported that, in H. undatus fruits, the onset of color change also occurs from $24^{\text {th }}$ to $25^{\text {th }}$ DAA, and, after 4 to $5 \mathrm{~d}$, they become completely red, confirming that the development of the pericarp color is related to the soluble solids content. Van To et al. (2002) stated that $H$. undatus fruits must be harvested when they acquire the red color, suggesting that the best indicator of pitaya flavor is the ratio, whose ideal value is close to 40 .

Ortiz and Takahashi (2015) verified that the physical and chemical characteristics evaluated were influenced by the maturation of pitaya fruits, with the exception of the longitudinal length. Thus, they concluded that $H$. undatus fruits in Paraná-Brazil reached physiological maturity between the $30^{\text {th }}$ and $32^{\text {nd }}$ DAA, proving this as the ideal period for harvesting the fruits since, in this period, the fruits have become completely red and have reached the soluble solids content, titratable acidity, $\mathrm{pH}$ and ratio recommended and characteristic for this species.
Many characteristics are important and essential in the designation of the ideal period for harvesting pitaya fruits. Therefore, determining the physiological maturity of the fruits is necessary to optimize the harvest and quality of the final product. According to Cavalini (2004), using more than one variable to characterize a maturity stage allows greater precision when classifying fruits in their stages.

\section{CONCLUSIONS}

For the pitaya, the number of days of the anthesis until the full development of the fruit is the most reliable variable to determine the timing of harvest. With this designation, it is possible to indicate the phase (physiological maturity) in which the fruits present characteristics that are favorable to this species, such as color, soluble solids content, and ratio, among others, making it possible to obtain a product with quality and consumer acceptability.

The place of production and edaphoclimatic conditions can interfere and cause variation in the period in which the fruits reach physiological maturity. Based on studies carried out in this area, the recommendation is to harvest fruits between the $25^{\text {th }}$ and $32^{\text {nd }}$ days after anthesis to avoid loss of the commercial value.

\section{ACKNOWLEDGMENTS}

The authors acknowledge the financial support of the Brazilian Federal Agency for the Support and Evaluation of Graduate Education (Coordenação de Aperfeiçoamento de Pessoal de Nível Superior - CAPES) for granting scholarships to the first author and the Araucária Foundation (Fundação Araucária) for the productivity grant provided to the second author.

Conflict of interests: The manuscript was prepared and reviewed with the participation of the authors, who declare that there exists no conflict of interest that puts at risk the validity of the presented results.

\section{BIBLIOGRAPHIC REFERENCES}

ADAWR, Australian Department of Agriculture and Water Resources. 2017. Final report for the review of biosecurity import requirements for fresh dragon fruit form Vietnam. Department of Agriculture and Water Resources, Canberra, Australia. 
Almanza-Merchán, J. Velandia D., and Y. Tovar. 2016. Propiedades fisicoquímicas durante el crecimiento y desarrollo de frutos de lulo (Solanum quitoense Lam.). Rev. Colomb. Cienc. Hortic. 10(2), 222-231. Doi: 10.17584/ rcch.2016v10i2.5065

Andrade, R.A., A.B.G., Martins, and M.T.H. Silva. 2007. Influência da fonte de material e do tempo de cura na propagação vegetativa da Pitaya Vermelha (Hylocereus undatus Haw). Rev. Bras. Frutic. 29(1), 183-186. Doi: 10.1590/S0100-29452007000100039

Arévalo-Galarza, M.L. and Y.D. Ortíz-Hernández. 2004. Comportamiento postcosecha del fruto de la pitahaya (Hylocereus undatus). Cact. Suc. Mex. 49(3), 85-90.

Ayub, R., M. Guis, M. Ben Amor, L. Gillot, J.P. Roustan, A. Latché, M. Bouzayen, and J.C. Pech. 1996. Expression of ACC oxidase antisense gene inhibits ripening of cantaloupe melon fruits. Nat. Biotechnol. 14(7), 862866. Doi: 10.1038/nbt0796-862

Bastos, D.C., R. Pio, J.A. Scarpare Filho, M.N. Libardi, L.F.P. Almeida, T.P.D. Galuchi, and S.T. Bakker. 2006. Propagação de pitaya 'vermelha' por estaquia. Ciênc. Agrotec. 30(6), 1106-1109. Doi: 10.1590/ S1413-70542006000600009

Cálix de Dios, H.C. and R. Castillo Martínez. 2008. Estudio sobre la pitahaya amarilla de la Península de Yucatán. Tróp. Rural 1(7), 31-35.

Camargo, A. and O.M. Moya. 1995. Estudio preliminar de la influencia del choque térmico en la inhibición de daños por frío en la pitaya amarilla (Acanthocereus pitaya). PhD thesis. Universidad Nacional de Colombia, Bogota.

Castellar, R., J.M. Obón, M. Alacid, and J.A. Fernández-López. 2003. Color proprieties and stability of betacyanins from Opuntia fruits. J. Agric. Food Chem. 51(9), 2772-2776. Doi: 10.1021/jf021045h

Castillo-Martínez, R., M. Livera-Muñoz, A.E. Brechú-Franco, and J. Márquez-Guzmán. 2003. Compatibilidad sexual entre dos tipos de Hylocereus (Cactaceae). Rev. Biol. Trop. 51(3-4), 699-706.

Castillo-Martínez, R., M. Livera-Muñoz, and G.J. Márquez-Guzmán. 2005. Caracterización morfológica y compatibilidad sexual de cinco genotipos de pitahaya (Hylocereus undatus). Agrociencia 39(2), 183-194.

Castillo-Martínez, R. and Y.D. Ortíz-Hernández. 1994. Floración y fructificación de pitajaya en Zaachila, Oaxaca. Rev. Fitotec. Mex. 17(1), 12-19.

Cavalcante, Í.H.L., A.B.G. Martins, G.B. Silva Júnior, L.F. Rocha, R. Falcão Neto, and L.F. Cavalcante. 2011. Adubação orgânica e intensidade luminosa no crescimento e desenvolvimento inicial da Pitaya em Bom Jesus-PI. Rev. Bras. Frutic. 33(3), 970-982. Doi: 10.1590/ S0100-29452011005000086

Cavalini, F.C. 2004. Índices de maturação, ponto de colheita e padrão respiratório de goiabas 'Kumagai' e 'Paluma'.
Ph.D dissertation. $\mathrm{PhD}$ thesis. Universidade de São Paulo, Piracicaba, Brazil.

Centurión Yah, A.R., R. Baéz Sañudo, M. Pérez Vergara, S. Solís Pereira, E. Mercado Silva, C. Saucedo Veloz, and E. Sauri Duch. 2000. Crecimiento, desarrollo y comercialización de la pitahaya (Hylocereus undatus) durante la postcosecha. Rev. Iberoam. Tecnol. Postcos. 2, 161-168.

Centurión Yah, A.R., S. Solís Pereira, C. Saucedo Veloz, R. Baéz Sañudo, and E. Sauri Duch. 1999. Variación de las principales características de la pitahaya (Hylocereus undatus) durante su maduración postcosecha. Hort. Mex. 7, 419-425.

Centurión Yah, A.R., S. Solís Pereira, C. Saucedo Veloz, R. Baéz Sañudo, and E. Sauri Duch. 2008. Cambios físicos, químicos y sensoriales en frutos de pitahaya (Hylocereus undatus) durante su desarrollo. Rev. Fitotec. Mex. 31(1), 1-5.

Chávez, S. and Y. Stevenson. 1992. Estudio del comportamiento de algunos parámetros, durante el curso de maduración de la pitaya amarilla (Cereus triangularis Haw). PhD thesis. Universidad Nacional de Colombia, Bogota.

Chacón-Padilla, K. and J. Monge-Pérez. 2017. Evaluación de rendimiento y calidad de seis genotipos de pepino de frutos largos (Cucumis sativus L.) cultivados bajo invernadero en Costa Rica, durante la época seca. Rev. Colomb. Cienc. Hortic. 10(2), 323-332. Doi: 10.17584/ rcch.2016v10i2.5069

Chitarra, M.L.F. and A.B. Chitarra. 2005. Pós-colheita de frutos e hortaliças: fisiologia e manuseio. $2^{\text {nd }}$ ed. UFLA, Lavras, Brazil.

Chuine, I., K. Kramer, and H. Hänninen. 2003. Plant development models. pp. 217-235. In: Schwartz, M.D. (ed.). Phenology: an integrative environmental science. Kluwer Academic Publishers, Dordrecht, NL. Doi: 10.1007/978-94-007-0632-3_14

Cordeiro, M.H.M., J.M. Silva, G.P. Mizobutsi, E.H. Mizobutsi, and W.F. Mota. 2015. Caracterização física, química e nutricional da pitaia-rosa de polpa vermelha. Rev. Bras. Frutic. 37(1), 20-26. Doi: 10.1590/0100-2945-046/14

Crane, J.H. and C.F. Balerdi. 2005. Pitaya growing in the Florida home landscape. HS 1068. Institute of Food and Agricultural Sciences (IFAS Extension), University of Florida, Orlando, FL.

De La Barrera, E. and P.S. Nobel. 2004. Carbon and water relations for developing fruits of Opuntia ficus-indica (L.) Miller, including effects of drought and gibberellic acid. J. Exp. Bot. 55(397), 719-729. Doi: 10.1093/jxb/ erh084

Donadio, L.C. 2009. Pitaya. Rev. Bras. Frutic. 31(3), 637929. Doi: 10.1590/S0100-29452009000300001

Esquivel, P. 2004. Los frutos de las cactáceas y su potencial como materia prima. Agron. Mesoam. 15(2), 215-219. Doi: 10.15517/am.v15i2.11916 
Esquivel, P., F.C. Stintzing, and R. Carle. 2007a. Comparison of morphological and chemical fruit traits from different pitaya genotypes (Hylocereus sp.) grown in Costa Rica. J. Appl. Bot. Food Qual. 81(1), 7-14.

Esquivel, P., F.C. Stintzing, and R. Carle. 2007b. Fruit characteristics during growth and ripening of different Hylocereus genotypes. Eur. J. Hortic. Sci. 72(5), 231-238.

Fernandes, D.R., R.A. Moreira, M.C.M. Cruz, J.M. Rabelo, and J. Oliveira. 2018. Improvement of production and fruit quality of pitayas with potassium fertilization. Acta Sci., Agron. 40. Doi: 10.4025/actasciagron. v40i1.35290

Garnica, G. and E. Quintero. 1994. Estudio preliminar de la influencia de las bajas temperaturas sobre algunas características de la maduración de la pitaya amarilla (Acanthocereus pitajaya). $\mathrm{PhD}$ thesis. Universidad $\mathrm{Na}-$ cional de Colombia, Bogota.

Gunasena, H.P.M., D.K.N.G., Pushpakumara, and M. Kariyawasam. 2007. Dragon Fruit Hylocereus undatus (Haw.) Britton and Rose. pp. 110-142. In: Pushpakumara, D.K.N., H.P.M. Gunasena, and V.P. Singh (eds.). Underutilized fruit trees in Sri Lanka. World Agroforestry Centre, New Delhi.

Gross, K.C., C.Y. Wang, and M. Saltveit. 2016. The commercial storage of fruits, vegetables, and florist and nursery stocks. Agriculture Handbook 66. $5^{\text {th }}$ ed. Department of Agriculture, Olympia, WA.

Junqueira, K.P., F.G. Faleiro, G. Bellon, N.T.V. Junqueira, K.G. Fonseca, C.A. Lima, and E.C. Santos. 2010. Variabilidade genética de acessos de pitaya com diferentes níveis de produção por meio de marcadores RAPD. Rev. Bras. Frutic. 32(3), 840-846. Doi: 10.1590/ S0100-29452010005000107

Kasso, M. and A. Bekele. 2018. Post-harvest loss and quality deterioration of horticultural crops in Dire Dawa Region, Ethiopia. J. Saudi Soc. Agric. Sci. 17, 88-96. Doi: 10.1016/j.jssas.2016.01.005

Kays, S.J. 1991. Postharvest physiology and handling of perishable plant products. Van Nostrand Reinhold, New York, NY. Doi: 10.1007/978-1-4684-8255-3

Le Bellec, F., F. Vaillant, and E. Imbert. 2006. Pitahaya (Hylocereus spp.): a new fruit crop, a market with a future. Fruits 61(4), 237-250. Doi: 10.1051/fruits:2006021

Lemos, L.M.C., L.C.C. Salomão, D.L. Siqueira, O.L. Pereira, and P.R. Cecon. 2018. Heat unit accumulation and inflorescence and fruit development in 'Ubá' mango trees grown in Visconde do Rio Branco-MG. Rev. Bras. Frutic. 40(2), e-491. Doi: 10.1590/0100-29452018491

Livera-Muñoz, M., Y.D. Ortíz-Hernández, R. Castillo-Martínez, F. Castillo-González, R. Martínez-Chávez, J.J. Ramírez-Delgadillo, A.J. Valencia-Botín, and J. A. Carrillo-Salazar. 2010. Pitahaya (Hylocereus spp.): problemas, logros y perspectivas. pp. 57-59. In: Cruz-Izquierdo, S., A.L.Y. Muratalla, and A.T.Y. Kato (eds.). La investigación al servicio del campo mexicano. Colegio de Postgraduados, Montecillo, Mexico.

Lorenzi, H., L. Bacher, M. Lacerda, and S. Sartori. 2006. Frutas brasileiras e exóticas cultivadas (de consumo in natura). Instituto Plantarum de Estudos da Flora, Nova Odessa, Brazil.

Luders, L. and G. McMahon. 2006. The pitaya or dragon fruit (Hylocereus undatus). Agnote D42. Northern Territory Government, Melbourne, Australia.

Marques, V.B. 2008. Propagação seminífera e vegetativa de pitaia (Hylocereus undatus (Haw.) Britton \& Rose). MSc thesis. Universidade Federal de Lavras, Lavras, Brazil.

Marques, V.B. 2010. Germinação, fenologia e estimativa do custo de produção da pitaia [Hylocereus undatus (Haw.) Britton \& Rose]. PhD thesis. Universidade Federal de Lavras, Lavras, Brazil.

Martínez, R. 2011. Relaciones entre genotipo, productividad y calidad de fruto en pitahaya (Hylocereus spp.). $\mathrm{PhD}$ thesis. Colegio de Postgraduados, Montecillo, Mexico.

Meráz, M.R., M.A. Gómez, and R. Schwentesius. 2003. Pitahaya de México: produción y comercialización en el contexto internacional. pp. 97-121. In: Flores, C.A. (ed.). Pitayas y pitahayas. CIESTAAM, Texcoco, Mexico.

Mizrahi, Y. and A. Nerd. 1999. Climbing and columnar cacti: new arid lands fruit crops. pp. 358-366. In: Janick, J. (ed.). Perspective in new crops and new crops uses. ASHS Press, Alexandria, VA.

Mizrahi, Y., A. Nerd, and Y. Sitrit. 2002. New Fruits for Arid Climates. pp. 378-384. In: Janick, J. and A. Whipkey (eds.). Trends in new crops and new uses. ASHS Press, Alexandria, VA.

Nerd, A., F. Gutman, and Y. Mizrahi. 1999. Ripening and postharvest behaviour of fruits of two Hylocereus species (Cactaceae). Postharvest Biol. Technol. 17(1), 3945. Doi: 10.1016/S0925-5214(99)00035-6

Nerd, A. and Y. Mizrahi. 1997. Reproductive biology of cactus fruit crops. Hortic Rev. 18, 321-346. Doi: 10.1002/9780470650608.ch7

Nerd, A. and Y. Mizrahi. 1999. The effect of ripening stage on fruit quality after storage of yellow pitaya. Postharvest Biol. Technol. 15(2), 99-105. Doi: 10.1016/ S0925-5214(98)00080-5

Nerd, A., Y. Sitrit, R.A. Kaushik, and Y. Mizrahi. 2002a. High Summer temperatures inhibit flowering in vine pitaya crops (Hylocereus spp.). Sci. Hortic. 96(1-4), 343-350. Doi: 10.1016/S0304-4238(02)00093-6

Nerd, A., N. Tel-Zur, and Y. Mizrahi. 2002b. Fruits of vine and columnar cacti. pp. 185-197. In: Nobel, P. (ed.). Cacti: Biology and uses. University of California Press, Berkeley, CA. Doi: 10.1525/ california/9780520231573.003.0011 
Nguyen, V.H., J. Campbell, H.H. Nguyen, and M.C. Nguyen. 2015. Development and implementation of GAP on pitaya in Vietnam: status and challenges. pp. 155164. In: Jiang, Y. L., P.C. Liu, and P.H. Huang (eds.). Improving pitaya production and marketing. Food and Fertilizer Technology Center, Taipei, Taiwan.

Ortiz, T.A. and L.S.A. Takahashi. 2015. Physical and chemical characteristics of pitaya fruits at physiological maturity. Genet. Mol. Res. 14(4), 14422-14439. Doi: 10.4238/2015. November.18.5

Ortíz-Hernández, Y.D. 2000. Hacia el conocimiento y conservación de la pitahaya (Hylocereus sp.). IPN-CONACYT-SIBEJ-FMCN, Oaxaca, Mexico.

Ortíz-Hernández, Y.D., M. Livera-Muñoz, M.T. Colinas -León, and J.A. Carrillo-Salazar. 1999. Estrés hídrico e intercambio de $\mathrm{CO}_{2}$ de la pitahaya (Hylocereus undatus). Agrociencia 33(4), 397-405.

Osuna Enciso, T., B. Bustamante Francisco, A.L. Mendoza Torres, and M.F. Zea. 2007. Fenología reproductiva y calidad del fruto de pitahaya (Hylocereus undatus) en Sinaloa, México. pp. 14-17. In: Proc. $12^{\text {th }}$ Congreso Nacional de la Sociedad Mexicana de Ciencias Hortícolas. Sociedad Mexicana de Ciencias Hortícolas. Zacatecas, México.

Osuna Enciso, T., M.E. Ibarra Zazueta, M.D. Muy Rangel, J.B. Valdez Torres, M. Villarreal Romero, and S. Hernández Verdugo. 2011. Calidad postcosecha de frutos de pitahaya (Hylocereus undatus Haw.) cosechados en tres estados de madurez. Rev. Fitotec. Mex. 34(1), 63-72.

Paula, C.C. and O.B.C. Ribeiro. 2004. Cultivo práctico de Cactáceas. UFV, Viçosa, Brazil.

Paull, R.E. and N.J. Chen. 2019. Overall dragon fruit production and global marketing. In: FFTC, http:// ap.fftc.agnet.org/ap_db.php?.id=1036; consulted: March, 2017.

Perween, T., K.K. Mandal, and M.A. Hasan. 2018. Dragon fruit: an exotic super future fruit of India. J. Pharmacogn. Phytochem. 7(2), 1022-1026.

Phebe, D., M.K. Chew, A.A. Suraini, O.M. Lai, and O.A. Janna. 2009. Red-fleshed pitaya (Hylocereus polyrhizus) fruit colour and betacyanin content depend on maturity. Int. Food Res. J. 16, 233-242.

Rodríguez, A. 1993. El cultivo de la pitahaya en Yucatán. Universidad Autônoma Chapingo, Maxcanú, Mexico.

Rodríguez, A. 2000. Producción y comercialización de pitahayas en México. Claridades Agropecuarias 84, 3-22.

Rudas, O.L. 1995. Contribución al estudio de las condiciones de almacenamiento en frío de la pitaya amarilla (Acanthocereus pitahaya). PhD thesis. Facultad de Agronomía, Universidad Nacional de Colombia, Bogota.

Santos, C.M.G., R.C. Cerqueira, L.M.S. Fernandes, F.W.N. Dourado, and E.O. Ono. 2010. Substratos e regulador vegetal no enraizamento de estacas de pitaya.
Rev. Ciênc. Agron. 41(4), 625-629. Doi: 10.1590/ S1806-66902010000400016

Silva, C.D., A.M.S.S. David, J.C. Figueiredo, J.L.R. Barbosa, and R.A. Alves. 2019. Fruit maturation stage on the physiological quality of maroon cucumber seeds. Pesqui. Agropecu. Trop. 49, e53188. Doi: 10.1590/1983-40632019v4953188

Silva, M.T.H., A.B.G. Martins, and R. Aparecida de Andrade. 2006. Enraizamento de estacas de pitaya vermelha em diferentes substratos. Rev. Caatinga 19(1), 61-64.

Socha, A.M.A. 2007. From Areoles to Zygocactus: an evolutionary masterpiece: a synopsis of the Family Cactaceae. The New York Botanical Garden, New York, NY.

Sornyatha, K. and P. Anprung. 2009. Bioactive compounds and stability of betacyanins from skin and flesh of red dragon fruit (Hylocereus polyrhizus (Weber) Britton \& Rose). J. Agric. Sci. 40(1), 15-18.

Stintzing, F.C. and R. Carle. 2006. Cactus fruits - more than colour. Fruit Processing. 16, 166-171.

Tel-Zur, N., S. Abbo, D. Bar-Zvi, and Y. Mizrahi. 2004. Genetic relationships among Hylocereus and Selenicereus vine cacti (Cactaceae): Evidence from hybridization and cytological studies. Ann. Bot. 94(4), 527-534. Doi: 10.1093/aob/mch183

Thé, P.M.P., V.D. Carvalho, C.M.P. Abreu, R.P. Nunes, and N.A.V.D. Pinto. 2001. Efeito da temperatura de armazenamento e do estádio de maturação sobre a composição química do abacaxi cv. Smooth cayenne L. Ciênc. Agrotec. 25(2), 356-363.

Tucker, G.A. 1993. Introduction. pp. 1-51. In: Seymour, G.B., J.E. Taylor, and G.A. Tucker (eds.). Biochemistry of fruit ripening. Chapman \& Hall, London. Doi: 10.1007/978-94-011-1584-1_1

Vaillant, F., A. Perez, I. Davila, M. Dornier, and M. Reynes. 2005. Colorant and antioxidant properties of red-purple pitahaya (Hylocereus sp.). Fruits 60(1), 3-12. Doi: 10.1051/fruits:2005007

Van To, L., N. Ngu, N.D. Duc, and H.T.T. Huong. 2002. Dragon fruit quality and storage life: Effect of harvesting time, use of plant growth regulators and modified atmosphere packaging. Acta Hortic. 575(72), 611-621. Doi: 10.17660/ActaHortic.2002.575.72

Warrington, I.J., T.A. Fulton, E.A. Halligan, and H.N. Silva. 1999. Apple fruit growth and maturity are affected by early season temperatures. J. Am. Soc. Hortic. Sci. 124(5), 468-477. Doi: 10.21273/JASHS.124.5.468

Weiss, J., A. Nerd, and Y. Mizrahi. 1994. Flowering behavior and pollination requirementes in climbing cacti with fruit crop potential. HortScience 29(12), 1487-1492. Doi: 10.21273/HORTSCI.29.12.1487

Wu, L.C., H.W. Hsu, Y.C. Chen, C.C. Chiu, Y.I. Lin, and J.A. Ho. 2006. Antioxidant and antiproliferative activities of red pitaya. Food Chem. 95(2), 319-327. Doi: 10.1016/j.foodchem.2005.01.002 
Wybraniec, S. and Y. Mizrahi. 2002. Fruit flesh betacyanin pigments in Hylocereus cacti. J. Agric. Food Chem. 50(21), 6086-6089. Doi: 10.1021/jf020145k

Xu, M., C. Liu, J. Luo, Z. Oi, Z. Yan, Y. Fu, S. Wei, and H. Tang. 2019. Transcriptomic de novo analysis of pitaya
(Hylocereus polyrhizus) canker disease caused by Neoscytalidium dimidiatum. BMC Genomics 20(10), 1-16. Doi: 10.1186/s12864-018-5343-0

Zee, F., C.R. Yen, and M. Nishina. 2004. Pitaya (Dragon Fruit, Strawberry Pear). Fruits \& Nuts 9, 1-3. 